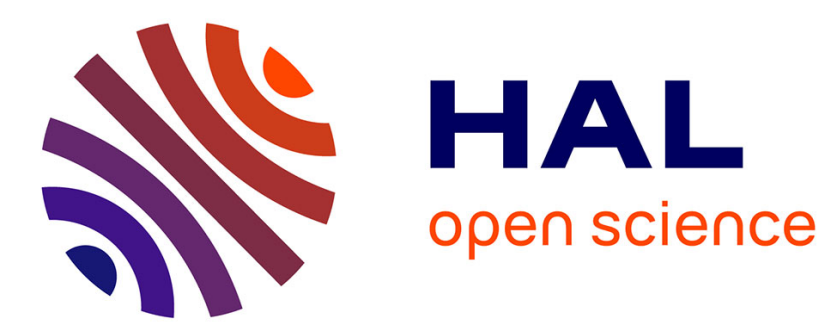

\title{
Public health policy vs colonial laissez-faire: STDs and prostitution in republican Shanghai
}

\author{
Christian Henriot
}

\section{To cite this version:}

Christian Henriot. Public health policy vs colonial laissez-faire: STDs and prostitution in republican Shanghai. Evelyne Micollier. Sexual Cultures in East Asia: The Social Construction of Sexuality and Sexual Risk in a Time of AIDS, Curzon Press, pp.159-182, 2004. halshs-00004067

\section{HAL Id: halshs-00004067 https://shs.hal.science/halshs-00004067}

Submitted on 9 Jul 2005

HAL is a multi-disciplinary open access archive for the deposit and dissemination of scientific research documents, whether they are published or not. The documents may come from teaching and research institutions in France or abroad, or from public or private research centers.
L'archive ouverte pluridisciplinaire HAL, est destinée au dépôt et à la diffusion de documents scientifiques de niveau recherche, publiés ou non, émanant des établissements d'enseignement et de recherche français ou étrangers, des laboratoires publics ou privés. 


\title{
PUBLIC HEALTH POLICY VS. COLONIAL LAISSEZ-FAIRE: STDS AND PROSTITUTION IN REPUBLICAN SHANGHAI
}

\author{
Christian HENRIOT \\ Institut d'Asie Orientale \\ Université Lumière-Lyon 2
}

\section{Introduction}

STDs are inseparably related to prostitution. Yet the nature of this relationship is far more complex than generally assumed as the issue is as much about actual medical problems as about social representations of the diseases. In Shanghai, the fear of the dangers of STDs in the late nineteenth century led a group of western physicians in the foreign settlements to call for strict measures of regulation and medical control of the prostitutes by the authorities. Similarly, in the 1920s the transmission of STDs by prostitutes was a central element of the abolitionist campaign launched by the Moral Welfare League. ${ }^{1}$ Finally, the Chinese authorities themselves took over the same discourse after W.W. II to legitimize their attempt at establishing a regulationist system in order to control prostitution and reduce the extent of STDs among the population. Chinese sources for the nineteenth century are almost completely silent on this topic, especially as they deal only with courtesans. The few references that exist are to be found 
in the medical journals published by missionaries. Because of their strong religious and moral tonality and the lack of precise scientific instruments to identify STDs, however, these early testimonies can hardly be relied on. The following paper, therefore, will only deal with the period after the 1911 revolution. I shall briefly present the general situation of prostitution and public health in China to avoid giving an unduly biased view of the Shanghai case, and the measures adopted by the foreign and Chinese authorities in their more or less determined fight against STDs.The second part will examine the issue of STDs in relation with the role of physicians among the population and the prostitutes.

\section{Coming to terms with STDs: Laissez-faire and Prejudice}

I shall not attempt here to reconstruct a history of STDs in China. The history of diseases, epidemics, and health issues in this country is still terra incognita for the most part. $^{2}$ In a previous study, I relied on medical journals and various testimonies by foreign missionaries and physicians to assess the extent of STDs in China and analyze what discourse, if any, such a phenomenon had generated within the medical profession. ${ }^{3}$ What the examination of these sources has revealed, however, was the high prevalence of STDs throughout the country as early as the mid-nineteenth century. This is something that struck all the foreign physicians who worked in China, whatever their location, even if they were far from being able to detect all the cases that came to them. ${ }^{4}$ As new instruments appeared, especially blood tests, the physicians who carried out surveys confirmed the high prevalence of the STDs in China ${ }^{5}$. They also noted that there was an acceleration of their diffusion due to the greater mobility of the population thanks to the modern means of transportation, but also as a result of the migrations caused by wars and the movement of troops in many parts of China. In the middle of the 1920 s - most of my data relate to this period - all the provinces were affected, even the most peripheral ones. STDs had by then become a major public health problem at a time when the health 
system in China was hardly emerging due to the weakness and lack of interest by the state. $^{6}$

The case of Shanghai, in this context, is therefore not exceptional, even if, as in all the large metropolises, especially as an international harbor city, the prevalence of STDs was particularly high. What distinguishes the city from the rest of the country are the efforts that were made in the field of public health, especially with regard to prostitution, and the high concentration of physicians and hospitals ${ }^{7}$. Elsewhere in China, the authorities generally refrained from establishing any regulation system of prostitution. The few examples that I came across were concentrated in Manchuria where such measures were imposed by the Japanese army. ${ }^{8}$ Among the large cities, only Peking did impose a medical examination of prostitutes and measures of seclusion until a diseased prostitute was fully cured. Such rules, however, were never implemented seriously. ${ }^{9}$

In Shanghai, the Shanghai Municipal Council (SMC) of the International Settlement implemented an ambiguous and contradictory policy that focused on the foreign residents and sojourners exclusively. The adoption of concrete measures for the benefit of the foreign community dates back to the 1920 s. It followed the debate on the abolition of prostitution and the visit by a delegation of the NCCVD, the association in charge of fighting STDs in Great Britain, in $1920 .{ }^{10}$ The SMC organized a series of meetings between the delegates and various local organizations and benefited from the conclusions of these exchanges. ${ }^{11}$ Among other things, the NCCVD delegates recommended the circulation of medical information to teenagers and adults, the establishment of cost-free institutions for the treatment of foreigners and the employees of the SMC suffering from STDs, and the creation of STD clinics in Chinese hospitals. ${ }^{12}$ Two years later, in reply to a letter of inquiry by the NCCVD on the outcome of its recommendations, the SMC stated that it had appointed a medical officer to take care of the problem of STDs. Due to other more pressing issues, however, the new appointee could not devote much time to 
this task. The SMC added that this was a much controversial topic, especially in Great Britain where the Board of Health had appointed a commission of inquiry to study the most appropriate means of fighting STDs. The Council was in the opinion it was better to wait for the conclusions of the commission before undertaking any particular policy. ${ }^{13}$

In 1923, the authorities of the International settlement eventually decided to open an evening anti-VD clinic within the General Hospital. Announcements were published in the press in English, Japanese, and Russian to inform the foreign residents of the existence of the new establishment. Patients almost immediately flocked in large numbers. During the first six months after its inauguration, the clinic received 1170 visits (for 191 patients). Afterwards the number of patients remained fairly stable, in spite of a drop related to the hostilities of 1937-1938 in Shanghai (Table 1). Patients suffering from syphilis were treated with six weekly injections of N.A.B., the famous "606", followed by nine injections of mercurial salt. A control test was done three months later. If it proved positive, the treatment was repeated along the same schedule over a period of two months. ${ }^{14}$ Very rapidly, the demand exceeded the capacity of the clinic. Fifty to sixty patients used to come every evening. Although the director of the establishment pointed out the services provided to short-term sojourners, especially seamen, the statistics showed that most of the patients were locals, most notably Russians. ${ }^{15}$ The SMC also planned the opening of a clinic reserved for women, but it lacked the will to overcome the reactions of hostility this project generated among a segment of foreign public opinion. $^{16}$

The surveys made among the patients on the place of origin of their disease with the view of determining the main zones on infection in the city drew the attention to the responsibility of the prostitutes located in the Chinese municipality or in the French settlement. ${ }^{17}$ Although the method was questionable in itself, the SMC complained about 
this situation and blamed the authorities of the neighboring districts. It also led the Council in 1926 to ask for a financial contribution from the French concession, as a compensation to the expenses incurred by the clinic. The French Conseil municipal rejected the demand, to the great displeasure of the SMC. ${ }^{18}$ In 1928 , twenty percent of the patients with a residence in the French Concession and another seventeen percent declared they had been infected by a prostitute in the Concession. ${ }^{19}$ This was not, however, the major issue at stake. The physicians of the clinic realized with the passing of time that their establishment could not cope with the whole issue of STDs, the sources of infection being multiple and largely beyond the control of the authorities. ${ }^{20}$ In 1934 , the same physicians acknowledged that the work of the clinic was no more than a palliative. The annual report of the SMC in 1937 even announced its closing after the beginning of the hostilities between Japan and China, but it must have reopened afterward since my data go up to $1940 .^{21}$ The authorities of the International settlement never cared but for the health of the foreign residents. In 1933, they were preparing a new version of the instruction booklet about STDs in..... Hindi. ${ }^{22}$

In the French Concession, the Conseil municipal did not adopt a particular policy until very late, despite the long tradition of regulationism both in France and in the Concession itself. In the nineteenth century, the Health officer had taken the initiative to ask for a regulation of prostitution and the medical examination of the prostitutes patronized by foreigners. ${ }^{23}$ His suggestion, however, had actually been implemented in the International Settlement, under the pressure of Edward Henderson, the SMC health officer. After much debate among the foreign ratepayers and a dispute with the French authorities - the French insisted on the seclusion of diseased prostitutes, not just medical control - a lock hospital was established in January 1877 under the auspices of the two settlements. It closed its doors with the advent of the abolitionist campaign in 1920. Afterward, no other institution took over again. ${ }^{24}$ 
In 1931, the Conseil municipal inaugurated a new municipal dispensary, but the facility was designed to provide free medical treatment to the poor. It did not take care of STDs specifically. ${ }^{25}$ Dr. Rabaute, the head of the Service d'hygiène et d'assistance, was not satisfied with this arrangement. He was keenly aware of the prevalence of STDs not only among the patients who came to the dispensary, but also among the general population of the Concession. He was also receptive to the criticisms by the SMC, which attributed to the French concession the major part of the cases treated in the anti-VD clinic. In November 1934, he presented a long report in which he emphasized the diffusion of STDs in Shanghai and the impossibility to rely on the Chinese state or on simple education to wipe out this scourge: "Il n'existe qu'un moyen de prophylaxie [...] c'est la lutte par le traitement de ces affections, de beaucoup le plus efficace [...] il nous faut accepter ici ce que nous ne pouvons pas empêcher» [There exists only one means of prophylaxis...[...] it is the fight through the treatment of these infections, by far the most efficient $[\ldots]$ we must accept here what we cannot prevent]. Rabaute recommended the creation of an anti-VD clinic that would be part of the municipal dispensary. It should be open outside of the normal working hours so that the largest number of people could have access to it. The establishment would provide medical care on a cost-free or paying basis, depending on the economic condition of the patient. Rabaute also urged the creation of similar clinics in all the hospitals of the Concession. The recommendations of Dr. Rabaute do not seem to have been implemented by the Conseil municipal. ${ }^{26}$

In the districts under Chinese jurisdiction, no initiative was ever taken during the same period. At the beginning of the Sino-Japanese war, the bureau of health was even dissolved and it was not recreated before 1941. In the absence of an access to the archives, I am not in a position to elaborate on its actual operation. It planned to get in touch with the French concession in order to adopt measures about STDs, but the annual 
report of the following year did not even mention this question. ${ }^{27} \mathrm{~A}$ major change occurred with the return to the city of the Nationalist authorities in 1945 . For the first time in the history of Shanghai the city came under the jurisdiction of a single municipal government. The regulationist policy that was carried out in the following years included an important dimension of fight against STDs, especially among prostitutes. One of the instruments of this policy was the anti-VD dispensary established in February $1946 .^{28}$ Two years later, its staff was composed of 25 persons, including six physicians and six nurses. ${ }^{29}$ To facilitate the access to medical care to the population at large, the bureau of Health ordered Shanghai hospitals to open special departments for the treatment of STDs. In 1948, sixteen establishments had complied. ${ }^{30}$

The prostitutes were subject to monthly examinations and, in case of infection, they had the choice between receiving a treatment at the dispensary or from one of the private physicians registered with the authorities. ${ }^{31}$ The police station of the Tilanqiao district even provided medicine to the diseased prostitutes, either free or at a price that varied according to their revenue. It seems that it was an isolated initiative for which I have not found any mention elsewhere. ${ }^{32}$ The prostitutes were not allowed to resume their activity for two years if they contracted syphilis. Since such a severe prohibition had negative counter-effects, the Bureau of Health suggested suppressing the two-year time limit as soon as the blood tests proved negative. The Bureau hoped that this less stringent policy would entice more prostitutes who were diseased to come forth for medical treatment without the fear of losing their source of revenue. ${ }^{33}$ Realizing the magnitude of the task, the municipal government oriented its policy toward a self-responsibility system of health care by the prostitutes themselves. ${ }^{34}$

The original project foresaw the medical examination of 200 women per day. ${ }^{35}$ In fact, the number of prostitutes received in the dispensary fell short from this objective. The 
documents established by the dispensary do not allow a correct assessment of the number of prostitutes who were examined since only the visits were computed. Moreover, the dispensary made a distinction between the visits, which served to provide treatment, and the examinations, which corresponded to the regular medical examinations of the prostitutes. Table 2 gives an idea of the number of calls in the establishment from 1946 to 1948. There was a clear increase over the whole period, but one is at pain to determine whether this relates to a greater number of women or to a larger number of examinations per prostitute. A paper by the director of the dispensary did however bring some light on the number of prostitutes concerned. For the two years 1946 and 1947, the dispensary examined respectively 1420 and 3550 women (cf. Table 2), a figure which was below the number of officially registered prostitutes (8000 in 1946, 3000 in 1947, 10.000 in 1948). ${ }^{36}$ The archives of the police confirm the lack of respect of the regulations by the prostitutes, even in the largest establishments of prostitution. In January 1948, a visit of inspection at the Taotao revealed that 55 women out of a total of 117 had not attended the medical examination in accordance with the prescribed schedule. At the Meixing, 20 prostitutes out of 53 did not the have the card issued by the dispensary. Finally, of the 33 inmates of the Haishang, 18 were diseased and had outdated cards. ${ }^{37}$

Table 2

\section{Number of visits and medical examinations}

at the municipal dispensary

(1946-1948) 


\begin{tabular}{|c|c|c|c|c|c|}
\hline & Prostitutes & Prostitutes & \multicolumn{2}{|c|}{ Number of cards issued by the dispensary } \\
\hline Year & $\begin{array}{c}\text { First } \\
\text { visit }\end{array}$ & Follow-ups & $\begin{array}{c}\text { First } \\
\text { examination }\end{array}$ & $\begin{array}{c}\text { Renewed } \\
\text { examination }\end{array}$ & $\begin{array}{c}\text { Total number } \\
\text { of examinations }\end{array}$ \\
\hline 1946 & 1310 & 6988 & 1022 & 2096 & 9749 \\
1947 & 1439 & 9426 & 1639 & 6689 & 17865 \\
1948 & 1955 & 12382 & 1192 & 11170 & 26502 \\
\hline
\end{tabular}

Source: Shanghai shi weishengju san nian lai gongzuo gaikuang, [1949], p. 9.

In spite of the facilities provided to the prostitutes, especially low-cost medical treatment, the dispensary observed that it failed to attract more than a quarter of the registered prostitutes. Most of them belonged to the lower categories and were often diseased. ${ }^{38}$ The Bureau of Health planned the creation of mobile teams that would visit the registered houses to accelerate the process of medical examination and treatment. The financial difficulties of the municipal government, however, forced the bureau to give up this project and to postpone it to more favorable times. ${ }^{39}$ One of the major difficulties in the implementation of the medical examination was the problem of coordination between the various services involved in health administration. During the first year of its existence, the Bureau of Health had to secure the assistance of a private laboratory to perform the blood tests. This procedure resulted in a ten-day delay between the medical examination and the transmittal of the results. With the establishment of a laboratory in its premises, the dispensary reduced the delay to three or four days. ${ }^{40}$ The most serious problem, however, was the lack of efficient liaison with the police. The latter was responsible for the administration of prostitution, but it was unable to forward the required documents on time. The Bureau of Health wrote repeatedly to complain about the delays that reached up to one month. The intervals that resulted from this inability just made the regular medical examination impossible. The women who were summoned with a delay often took the pretext of their menstrual period to shun examination. ${ }^{41}$ 
The ambassador of the United States in China as well as the American military medical officers exerted strong pressures on the Chinese municipal government to impose strict medical control on the prostitutes. ${ }^{42}$ The Chinese authorities frequently received official queries about women who were suspected of having infected an American soldier (who since then had returned home). When the Chinese police eventually managed to trace back the prostitute a few months later on the basis of the much imprecise information provided by the U.S. army, she was generally no longer in the establishment concerned or the latter had closed. ${ }^{43}$ The foreign military authorities also asked the municipal government to ban prostitutes in the vicinity of the quarters where their troops were stationed. $^{44}$

\section{People, Medicine and STDs: Anxieties and Profits}

One of the major causes of the spread of STDs in China was without any doubt the lack of treatment or the absorption of totally inefficient medicine. In 1925, a gynecologist noted that at least a quarter of the 2837 patients she had seen over eight years were or had been affected with STDs. Seventy percent of the cases of sterility she had met had their origin in untreated gonorrhea. ${ }^{45}$ Two years later, another medical survey on 2500 persons showed that 90 percent of the syphilitics had received no treatment of a modern type. ${ }^{46}$ According to the writings of these physicians and to the scattered evidence gathered in the press or the archives, it seems that the population, especially the prostitutes, availed themselves the services of traditional native physicians rather than those of westerntrained doctors. ${ }^{47} \mathrm{We}$ cannot generalize this posture to the whole Republican period or to all social groups. Probably, economics often dictated such a choice. The treatments prescribed by native physicians were much less expensive than the medicines imported from the West. The traditional treatment consisted in inhalations or absorption of 
mercury or calomel. ${ }^{48}$ An author noted that when the first treatment had failed, the unsatisfied patients turned toward Western medicine. ${ }^{49}$

The spread of STDs created a profitable market for all kinds of physicians and medicines. The Shanghai press abounded in advertisements by medical practitioners specializing in these diseases (hualiuke) or in medicines with miraculous curing virtues. Similar advertisements have reappeared in the streets of Chinese cities since the early 1980s in the form of small posters pasted on walls. In the Republic, some physicians made a living from just performing injections of "606" or " 914 ", the two main products for the treatment of syphilis before the introduction of antibiotics. ${ }^{50} \mathrm{Wu}$ Lien-teh, a respected physician, indicated that in Harbin, a city of 300,000 inhabitants, there were more than 200 private "anti-VD clinics". By 1927, physicians charged 20 to 30 yuan per injection, which was much more profitable than providing advice on prophylaxis. ${ }^{51}$ In Shanghai, a physician was said to have hired a few jobless fellows who sat in his waiting room to convey the idea that his talent was much in demand, and attract more customers. ${ }^{52}$ Medicines were relatively expensive. In 1928, the "Heisidian" — a new product imported from Germany according to an advertisement - cost three yuan for one box. A full treatment required three boxes. A bottle of "606" — two injections — was sold seven yuan. ${ }^{53}$ In the beginning of the 1940 s, the cost of a full treatment ranged from seventy to several hundred yuan. ${ }^{54}$

The case of Shanghai may however be particular as one Chinese historian has demonstrated in a study of the medical advertisements published in the Shen Bao, the main Shanghai daily, between 1912 and $1927 .{ }^{55}$ Although sex was omitted or hidden, or even repressed in the public arena or in social contacts, it was expressed under various guises through pressures on the individual, especially men. There was a latent male anxiety toward all that was related to sex, which merchants were apt to use to make sex 
the central factor of diseases. A large number of ordinary illnesses were therefore attributed to a weakness of genital organs or to excessive sexual activity. ${ }^{56}$ The profusion of advertisements for medicines designed to treat STDs, which represented the largest part of medical advertisements, were only one element of a more general craze for sexual revitalization. The period chosen by this historian is arbitrary as it takes as its limits two dates in political history. The chronological scope of such a study needs to be expanded. As early as the end of the 1890 s, the Shen Bao ran announcements on pills designed to cure gonorrhea (baizhuowan). The same trademark was still on sale in the $1920 \mathrm{~s}^{57}$ Through their message (text or image), these advertisements exploited the feeling of anxiety STDs generated. They explicitly associated these diseases with prostitution, juxtaposing for instance the face of a beautiful woman and a death skull.

The authorities made some attempts at controlling the trade in these medicines. In the police archives, I have several times come across a bunch of small newspapers (the socalled mosquito newspapers) of the same day. All the advertisements for such medicines had been carefully circled with a red pen. ${ }^{58}$ The police used to carry out investigations on the producers of such medicine. An analysis of the content of these newspapers showed that they carried a high number of advertisements for anti-VD medicines. For instance, on April 27, 1930 my reading of various newspapers produced the following figures ${ }^{59}$ :

$\begin{array}{lcr}\text { Xinwenbao (The News): } & 46 & \\ \text { Shishi xinwen (China Times): } & 7 & \\ \text { Shen Bao : } & & 16\end{array}$

The large number of advertisements certainly reflected the extent of the demand for such products. Many patients preferred to treat their disease by themselves, for the sake of discretion or economy. Some companies even proposed their products by 
correspondence. ${ }^{60}$ The diseased had a large choice of medicines, but they also ran the risk of becoming victims of their credulity. Charlatans were not rare among physicians, in spite of the control by the authorities, and a 1942 Shanghai guide recommended to newcomers to seek the advice of reliable friends before going to see a "flower and willow" doctor (hualiu yisheng) ${ }^{61}$ Nevertheless, these advertisements did not necessarily convey a negative image of prostitution. Patronizing prostitutes was considered as a normal act of life, but this habit could sometimes have undesirable consequences customers had to face. Altogether, however, prostitutes were indeed singled out in the transmission of STDs.

What looks surprising is the complete absence of any recommendations about the use of condoms before 1945. This may be related to the fact that I had no access to the small booklets that were distributed to seamen upon their arrival in Shanghai or to similar literature distributed by the Shanghai Municipal Council to the foreign population. Nevertheless, unless self-censorship excluded the public mention of such recommendations, none of the papers published in the two main medical journals ever referred to this possibility, even when the author dealt with STDs. Wu Lien-teh proposed in 1927 the sale of cheap prophylactic products, but it seems he intended them for prostitutes only. ${ }^{62}$ In a less technical genre, no guide of Shanghai, nor any "gallant's compass" (piaojie zhinan) advocated the use of condoms while they warned their readers against the high risk of getting infected when patronizing the lower classes of prostitutes. ${ }^{63}$ It was only in 1945 that the police explicitly ordered the houses of prostitution to purchase prophylactic products and instruments for the inmates and the use of condoms by customers. In 94 percent of the cases checked by the police, these instructions were not respected. ${ }^{64}$ 
The more prevalent STDs at that time were syphilis, gonorrhea, and soft chancre. Gonorrhea represented the highest number of cases in all the statistical samples I have found. At the Shantung Hospital, it made up 48.5 percent of all the new cases of STDs in 1923. Syphilis and soft chancre shared the rest with 33.8 and 17.7 percent respectively. ${ }^{65}$ Table 1 summarizes the data provided by the anti-VD clinic of the Shanghai Municipal Council from 1923 to $1940 .{ }^{66}$ Gonorrhea always ranks first with an average of forty percent of all cases, followed by syphilis (18.8 percent) and soft chancre (18.5 percent). ${ }^{67}$ It is difficult to assess the extent of STDs among the population at large. The registers of the General Hospital for the period 1875-1922 give an average rate of 9.9 percent of STD infections among its patients. The Shantung Road Hospital registered a lower rate of 6.6 per cent from 1870 to 1922 . These figures are probably underestimated because of the absence of blood tests for the most part of the period of reference. ${ }^{68}$ The director of the municipal dispensary, $\mathrm{Yu}$ Wei, put the number of syphilitics at 10 percent of the population in 1938 and 15 percent in 1945. Gonorrhea, in his opinion, affected one half of the population. He drew these figures from a study of the statistics held by the various hospitals of the city. ${ }^{69}$ The blood tests campaigns carried out after 1949, however, did not

produce such alarming results. ${ }^{70}$ Among the 31,861 persons examined in three hospitals from 1945 to 1950 , only nine percent had a positive reaction to STD detection tests. ${ }^{71}$ These data raise the same problem. Even if the conclusions of the pre-war physicians were, as I think, biased by the prevailing social imaginary constructed around the issue of prostitution, the prevalence of STDs in Shanghai must have been superior to the rates computed from the hospital registers.

\section{Prostitutes and STDs}

What about the prostitutes as the "source of all evils"? The data I have collected are all partial and subject to discussion. I shall compare them with surveys made among various 
groups of prostitutes in other Chinese cities. The overall image is undoubtedly disturbing. According to the declarations made by the patients of the SMC's anti-VD clinic, they contracted their infection from Chinese prostitutes in most cases (Table 3). Given the Chinese social context of strict separation of men and women, they could hardly have been infected from another source.

Table 3

Sources of infection according to

the declarations of patients (1926-1929)

\begin{tabular}{|l|c|c|c|}
\hline Source of infection & $\mathbf{1 9 2 6}$ & $\mathbf{1 9 2 7}$ & $\mathbf{1 9 2 9}$ \\
\hline Chinese prostitutes & 64 & 70 & 75 \\
Russian prostitutes & 27 & 20 & 12 \\
Japanese prostitutes & 5 & $* *$ & $* *$ \\
Other prostitutes & 4 & 10 & 13 \\
\hline
\end{tabular}

Sources: Shanghai Municipal Council, Report for the Year 1926, op. cit., p. 195; Report for the Year 1927, op. cit., p. 183; Report for the Year 1929, op. cit., p. 150

The articles published in medical journals confirmed beyond any doubt the poor state of health of the prostitutes. A Chinese physician, Daniel Lai, wrote several papers on syphilis in China. In 1930, he published the results of a survey carried out among 137 prostitutes from Shanghai (104), Nanjing (22) and Suzhou (11). These women had quit prostitution and were living in refuges. On average, 49 percent had syphilis, those from Shanghai having the lowest rate with 40.4 percent. ${ }^{72}$ This sample, however, was small and random. There exists two supplementary statistical series on the health of Shanghai prostitutes. The first one, presented in table 4, was elaborated by the municipal dispensary for 1946 and 1947. It reveals that more than eighty percent of the women had a venereal infection. The distribution of the diseases was different from the one observed 
among the patients of the SMC's anti-VD clinic. Syphilis accounted for eighty percent of all infections, but the director thought that the smear method used to detect them was not reliable. ${ }^{73}$ Furthermore, according to him, 95 percent of the prostitutes had contracted gonorrhea. $^{74}$

Table 4

The prevalence of STDs among the prostitutes examined at the municipal dispensary (1946-1947)

\begin{tabular}{|l|c|c|c|c|}
\hline \multirow{3}{*}{$\begin{array}{l}\text { Number of examined women } \\
\text { Total number of infections }\end{array}$} & $\mathbf{1 9 4 6}$ & $\mathbf{1 9 4 6}$ & $\mathbf{1 9 4 7}$ & $\mathbf{1 9 4 7}$ \\
\cline { 2 - 5 } Number of diseased women & 1420 & & 3550 & \\
\cline { 2 - 5 } Syphilis & 1062 & & 2611 & \\
\cline { 2 - 5 } Gonnorhea & 931 & $87,7 \%$ & 2205 & $84,5 \%$ \\
Chancroid & 885 & $83,3 \%$ & 2069 & $79,2 \%$ \\
Others & 174 & $16,4 \%$ & 533 & $20,4 \%$ \\
\hline & 1 & $0,1 \%$ & 5 & $0,2 \%$ \\
\hline Primary syphilis & 2 & $0,2 \%$ & 4 & $0,2 \%$ \\
Secundary syphilis & 32 & $4 \%$ & 24 & $1 \%$ \\
Tertiary syphilis & 21 & $2 \%$ & 46 & $2 \%$ \\
\hline
\end{tabular}

Source : Yu Wei, "Shanghai changji wu bai ge an diaocha», p. 13

In this table the total number of infections was superior to the number of women, which means that some prostitutes suffered from two diseases at the same time. ${ }^{75}$ Moreover, most of the syphilitic prostitutes had reached the third stage of the disease. These data may be biased since the dispensary received mostly prostitutes from the lower categories, who had been in the trade for a long time and more exposed to the risk of infection. ${ }^{76}$ The second series of statistics come from the first group of 501 prostitutes arrested by the police in 1951 . Healthy women represented only 10.9 percent of the whole group. The others had syphilis (11.5 percent), gonorrhea (30 percent) or both at the same time (47.6 
percent). As in the previous sample, a large number ( 73.7 percent) had reached the third stage of syphilis. $^{77}$

The surveys made in various forms in other Chinese cities before 1949 also confirmed the prevalence of STDs among prostitutes. A 1948 medical survey among 576 prostitutes and 95 taxi dancers ${ }^{78}$ in Qingdao (Shandong) showed that 80 and 60 percent of them respectively had syphilis. ${ }^{79}$ In the same year, two physicians carried out a survey among the prostitutes registered with the Beijing municipal dispensary. They selected 876 women they followed over a period of 41 days. ${ }^{80}$ This unusual procedure demonstrated that 89 percent of the prostitutes got an infection during the time of the survey. ${ }^{81}$ In 1950 , 96 percent of the 1303 Beijing prostitutes interned by the authorities were diseased, of whom 1107 had syphilis. ${ }^{82}$ It is not necessary to multiply the examples. Chinese prostitutes in their great majority suffered from venereal infections that in most case went unnoticed, untreated or were treated with inadequate medicines. The consequences of this sad reality were dreadful when the prostitutes left the trade and went back to their villages.

The practices of the Chinese prostitutes partly explain the high degree of infection they presented, even if some establishments took precautionary measures. In the Taotao, a physician was employed full time to treat the inmates. His honorarium and the cost of medicines, however, were borne by the prostitutes. The latter complained about the high tariff was imposed on them (80,000 yuan per month including laundry service) ${ }^{83}$ Health regulations were very rudimentary. The prostitutes were required to wash their genitalia only once a day and did not apparently used condoms. ${ }^{84}$ In most houses, such minimal care was not even guaranteed. To protect themselves against STDs, especially syphilis, some women took regular injections of Salvarsan (the famous "606"). In 1947, a prostitute stated that she received two injections per month at a cost of 20 U.S. dollars 
(200,000 yuan) each. The same medicine cost only one dollar at the municipal dispensary. The price of the injections of Salvarsan followed the curve of inflation. One year before, it cost only 50,000 yuan per injection. When the prostitutes did not have enough money, the madam loaned the required amount and received the reimbursement the following day or when the women had revenues. ${ }^{85}$ A diseased woman who was treated in 1948 by a physician introduced by her madam paid 80 U.S. dollars $(800,000$ yuan) for the first injection of Neosalvarsan. The following two were charged 40 dollars each. ${ }^{86} \mathrm{~A}$ document of the Bureau of Health noted that more than sixty percent of the private practitioners and hospitals did not use the most efficient medicines to treat STDs. Although antibiotics were available, they still prescribed the older arsenic-based products. ${ }^{87}$ The municipal dispensary itself lacked the funds to purchase the most efficient treatments that could cure a person in a few hours in the case of gonorrhea or in a few days for syphilis. Instead, months of treatment were required that discouraged the prostitutes to come as they knew their license would be withdrawn. ${ }^{88}$

The fate of the diseased women could sometimes take a tragic turn. The inconveniences or even the pains caused by their infections during sexual intercourse led the prostitutes to refuse customers. Some madams did not have the least consideration for the health condition of the women, while they denied them the possibility to get a treatment, and forced them to continue their activity. Those who became seriously ill had to give up at one point until they were cured. Yet, it is impossible to say to what extent the prostitutes had the freedom to make such a choice and to receive a treatment. This depended very much on the status under which they had been involved into prostitution (sold, pawned or free). ${ }^{89}$ The press provides examples of women who were exploited to the very end, whatever the period. In 1899, a prostitute (yeji) who was in the last stage of syphilis was sent to a private clinic in the French Concession. After ten days, as her state of health was becoming critical, the director refused to keep her because of the other patients and had 
her sent over to the brothel house. The madam did not want her either and threw her out in the street where a policeman picked her up some time later. ${ }^{90}$ In 1909 , the police discovered during a visit of inspection the undeclared cadaver of a prostitute who had died of her diseases. ${ }^{91}$ In 1921, the Garde Municipale found in a brothel a woman who was seriously ill and to whom the madam had refused all medical treatment. ${ }^{92}$ Three years later, a diseased huayanjian ${ }^{93}$ abandoned in the street by the owner of the establishment where she worked died in a small lodging house. ${ }^{94}$ The cases reported in the press are isolated affairs, but how many women suffered the same fate? This was not the majority of them, but these extreme cases reveal the degree of indifference, egoism, and cynicism that could prevail in the relations of the madams with the prostitutes.

\section{Conclusion}

The patronizing of prostitutes by customers who hardly took any care of their own health condition translated into the large diffusion of STDs in China. By 1937, there were around 30 to 35 millions syphilitics, a figure that continued to increase in the following

decade. ${ }^{95}$ It is no accident that the new regime launched a vigorous campaign of eradication after 1949. STDs had become a public scourge. ${ }^{96}$ This situation resulted first from the lack of sanitary infrastructures that could accommodate the needs of the prostitutes and the population at large. Public health, a concept imported at a later stage from the West, was never on top of the list of priorities of the successive Chinese governments. In Shanghai, the establishment of a full-fledged public health administration in the Chinese municipality awaited 1927. In spite of its accomplishments during the following decade, its action was not directed toward the issue of STDs. ${ }^{97}$ In the foreign settlements, the authorities made a weak attempt to put a rein on the spread of these diseases as they focused only on very small segments of the population, namely the permanent or transient foreign communities, and on the prostitutes who catered for their 
needs. These efforts were fundamentally useless since they tackled only a small part of the problem.

Although as early as the 1920s some voices raised the issue of prevention through education - this was the dominant position among Shanghai physicians as expressed by the Shanghai Medical Association - nothing of that kind was ever undertaken by the Shanghai Municipal Council, the French Concession or the Chinese municipal government. What prevailed was a logic of control and repression that targeted those who were considered as the source of all problems: the prostitutes. It is true that the vast majority of prostitutes carried diseases. It is equally true that they hardly availed themselves of the services of a doctor, even after the introduction of antibiotics in 1945, although most of them carried STDs that must have left severe sequels a long time after their exit from prostitution. Yet, their attitude was not so much the consequence of a lack of consciousness about the "perils of the trade", about hygiene standards or the existence of medical treatments. It was above all the result of a complex mix that actually inhibited any such possibility. This mix included the conditions under which these women were recruited and worked, their economic condition, and the policies implemented by the foreign and Chinese authorities. The latter ran counter its intended purposes simply because they were designed out of prejudiced ideas about prostitution and prostitutes, without any direct contact with them or any attempt to get a proper knowledge of this milieu.

For almost a quarter of a century, the Chinese government was able to eradicate prostitution from its cities. ${ }^{98}$ The return to a more open economic and social system, with increased exchanges and mobility both within and outside the domestic realm, has created the conditions for the forceful re-emergence of prostitution throughout the country. While no direct parallel with the Republican period can be traced, the dominant mode of intervention by the Chinese authorities has been stigmatization and repression. ${ }^{99}$ As in the past, the approach to the problem of prostitution and STDs - a problem made 
more sensitive with HIV and AIDS - is derived from prejudiced views rather than a genuine attempt to confront the social dynamics that run below prostitution and from a deliberate policy of imposing a blackout on these issues, especially the extent of HIV in China, both internally and externally. Demonizing HIV and AIDS can only contribute to further driving "underground" those who are infected, especially prostitutes, and promoting the extension of the pandemics in China.

1 The Moral Welfare League was an organization established in 1918 by a group of Protestant missionaries and activists to put an end the policy of medical control of the prostitutes by the Shanghai Municipal Council in the International Settlement and to eliminate prostitution from the settlement. See Henriot, Christian (2001) Prostitution and Sexuality in Shanghai. A Social History (1849-1949), New York, Cambridge University Press.

${ }^{2}$ The major studies of diseases in China have focused on plague, see for instance Benedict, Carol (1996) Bubonic Plague in Nineteenth-Century China, Stanford, Stanford University Press.

${ }^{3}$ Henriot, Christian (1992) "Medicine, V.D., and Prostitution in Pre-Revolutionary China," Social History of Medicine $\mathrm{V}: 1$, pp. $95-120$

${ }^{4}$ A woman physician wrote: "Syphilology was not so widely disseminated in those days [mid-1890s] as it is now, not even among practicing physicians. In many cases, we did not recognize syphilis when we met it and in others, we did not know exactly how to treat it". Fearn, Anne W. (1939) My Days of Strength: An American Woman Doctor's Forty Years in China, New York, Harper \& Brothers Publishers, p. 59.

${ }^{5}$ Pasteur's work opened the way to the discovery of transmissible diseases. Gonococcus, the pathogenic agent of gonorrhea, was identified in 1879, but it was not before 1905 that the treponema pallidum, the microbe of syphilis was discovered. The following year saw the invention of the first blood test (Wassermann) that could reliably detect a syphilitic infection. Quetel, Claude (1990) History of syphilis, Baltimore, The Johns Hopkins University Press, pp. 140-141.

${ }^{6}$ See the summary established in 1937 by Frazier, Chester N. (1937) "The Prevention and Control of Syphilis," Chinese Medical Journal 51: January, pp. 1043-46. On the development of public health in Nationalist China, see Yip Ka-che (1995) Health and National Reconstruction in Nationalist China. The Development of Modern Health Services, 1928-1937, Ann Arbor, Association for Asian Studies.

${ }^{7}$ Health issues were a major source of concern for Westerners from the onset. It was one of the major driving motives that led to the establishment and development of a municipal administration in the International Settlement. The reference on this topic is MacPherson, Kerrie L. (1987) A Wilderness of Marshes. The Origins of Public Health in Shanghai, 1843-1893, Oxford, Oxford University Press. On public health in a Chinese city, see Rogaski, Ruth (1996) "From protecting life to protecting the nation: The emergence of public health in Tianjin, 1859-1953," doctoral dissertation, Yale University.

${ }^{8}$ Wu, Lien-teh (1927) "The Problem of Venereal Diseases in China," China Medical Journal, vol. 41: January, p. 30

9 "Commercialized Vice in China" (1922) National Medical Journal 8:3, p. 397

${ }^{10}$ In 1913, the British government instituted the Royal commission on venereal diseases which presented its conclusions three years later. To implement the measures proposed by the commission, a National Council for Combating Venereal Diseases (NCCVD) was established. It was an organization of volunteers recognized by the ministry of Health as the agent of propaganda in the fight against venereal diseases 
throughout the country. The members of the Royal commission were appointed to the executive board of the Council. Peter, W.W. (1921) "Fighting Venereal Disease Openly," China Medical Journal 35: January, p. 62 and p. 64

${ }^{11} S B, 9$ Dec. $1920 ; 17$ Dec. 1920.

${ }_{12}$ Shanghai Municipal Council Report for the Year 1920, Shanghai, Kelly \& Walsh, p. 262-265A.

${ }^{13}$ Shanghai Municipal Council Report for the Year 1922, op. cit., pp. 308-309A. The Shanghai Municipal Council also emphasized STDs were only one of the contagious diseases against which its board of Health was fighting.

${ }^{14}$ Shanghai Municipal Council Report for the Year 1923, op. cit., pp. 123-124. On average, the number of visits per patient rose to thirty after 1925 when the clinic was well established. This is an indication of the serious follow that was performed on patients. This figure was computed from the data in Table 1.

${ }^{15}$ Many seamen preferred to go to the dispensary rather than declaring their disease to their own medical officer. Besides the lack of appropriate treatment on board, they feared the financial penalties that would result from their being put on sick leave. Shanghai Municipal Council, Report for the Year 1924, op. cit., pp. 148-149; Report for the Year 1926, op. cit., p. 195; Report for the Year 1927, op. cit., p. 182.

${ }^{6}$ Shanghai Municipal Council, Report for the Year 1924, op. cit., p. 148; Report for the Year 1925, op. cit., p. 134.

${ }^{17}$ Shanghai Municipal Council, Report for the Year 1926, op. cit., p. 195; Report for the Year 1927, op. cit., p. 183.

${ }^{18}$ Minutes of the Commission d'administration municipale, 29 Dec. 1926, Ordonnances consulaires (Jul. 1926-Dec. 1928), Archives diplomatiques, Nantes. The Shanghai Municipal Council publicly expressed its disappointment in its 1927 annual report: "It is very much to be regretted that the administration of the French Concession have declined to contribute toward the cost of maintaining the clinic". Shanghai Municipal Council, Report for the Year 1927, op. cit., p. 183.

${ }^{19}$ Shanghai Municipal Council, Report for the Year 1928, op. cit., p. 160

${ }^{20}$ Shanghai Municipal Council, Report for the Year 1931, op. cit., p. 175.

${ }^{21}$ Shanghai Municipal Council, Report for the Year 1934, op. cit., p. 137; Report for the Year 1937, op. cit., p. 153

${ }_{22}$ Shanghai Municipal Council, Report for the Year 1933, op. cit., p. 170.

${ }^{23}$ Henriot, Christian (2001) Prostitution and Sexuality in Shanghai. A Social History (1849-1949), Cambridge/New York, Cambridge University Press, chap. 11.

${ }^{24}$ On the establishment of the lock hospital and the adoption of various control measures in the XIXth century, see the excellent chapter of MacPherson, Kerrie L. (1987) A Wilderness of Marshes. The Origins of Public Health in Shanghai, 1843-1893, Oxford, Oxford University Press, pp. 213-258.

${ }^{25}$ Le Journal de Shanghai, 4 June 1931

${ }^{26}$ Report dated 23 November 1934, Archives diplomatiques, Nantes, Box No 39

${ }^{27}$ Yewu baogao (Annual report) (1941) Shanghai, Shanghai tebie shi weishengju bian, Shanghai, p. 1 and p. 19; Yewu baogao (Annual report) (1942) Shanghai, Shanghai tebie shi weishengju bian, Shanghai.

28 The dispensary was officially inaugurated on $1^{\text {st }}$ December 1945 , but because of problems of organization it did not receive prostitutes before February 1946. Letters of the Bureau of Health, 14 Feb. 1946, Police Archives (1945-1949), file 011-4-269; 19 Feb. 1946, Police Archives (1945-1949), file 0114-261.

${ }^{29}$ Organization regulations of the dispensary, 5 Feb. 1948, Police Archives. (1945-1949), file 011-4-269.

${ }^{30}$ Instruction of the Bureau of Health, Oct. 1946; letter of the Bureau of Health, $1^{\text {st }}$ May 1948, Police Archives (1945-1949), file 011-4-269.

31 "Changji jianyan buzou shuoming" (Instructions on the procedure of examination of prostitutes), Police Archives (1945-1949), file 011-4-269.

${ }^{32}$ Document of the Bureau of Police, Oct. 1946, Police Archives (1945-1949), file 011-4-269.

${ }^{33}$ Letter of the Bureau of Health, 2 Dec. 1946, Police Archives (1945-1949), file 1-10-246 (May 1946-Jan. 1949).

${ }^{34}$ Letter of the mayor, 8 Dec. 1947, Police Archives (1945-1949), file 6-19-666.

${ }^{35}$ Document of the Bureau of Police, 18 Feb. 1946, Police Archives (1945-1949), file 011-4-269.

${ }^{36} \mathrm{Yu}$ Wei, "Shanghai changji wu bai ge an diaocha," op. cit., p. 10. The arrested prostitutes who did not possess a card from the dispensary were fined or sent to jail for two or three days. Police Archives (19451949), file 011-4-171: "Jinü bu zhao guiding jianyan shenti an" (Cases of breach of regulation on the 
sanitary control of prostitutes), Dec. 1947-May 1948. On the Nationalist policy toward prostitution, see Henriot, Christian (2001) Prostitution and Sexuality in Shanghai. A Social History (1849-1949), Cambridge/New York, Cambridge University Press, chap. 13.

${ }^{37}$ Police report, 30 Jan. 1948, Police Archives (1945-1949), file 011-4-161: Aug. 1947-July 1949.

${ }^{38}$ Letter of the Bureau of Health, 30 Oct. 1946, Police Archives (1945-1949), file 011-4-269.

${ }^{39}$ Letters of the mayor, 15 June 1946; 12 Aug. 1946; undated project of the Bureau of Health; Letter of the bureau, 6 Aug. 1946, Police Archives (1945-1949), file 011-4-261.

${ }^{40} \mathrm{Yu}$ Wei, "Jin chang yu xingbing fangzhi" (The prohibition of prostitution and the prevention of venereal diseases), Shizheng pinglun (The Municipal affairs weekly), vol. 9, No 9/10, 1948, p. 18.

${ }^{41}$ Letters of the Bureau of Health, 27 Sept. 1946; 22 Oct. 1946, Police Archives (1945-1949), file 011-4269.

${ }^{42}$ Letter of the Bureau of Health, 8 June 1946; report of the medical service of the U.S. army in a file of the Bureau of Health, 22 June 1946, Police Archives (1945-1949), file 011-4-269.

${ }^{43}$ Two letters from military medical services in the United States, 2 Dec. 1946; 9 Sept. 1947; Two letters from the headquarters of the U.S. Navy in Shanghai, 2 Jan. 1946; 3 Oct. 1946, Police Archives (19451949), file 011-4-269; survey report, March 1948, Police Archives (1945-1949), file 011-4-269.

${ }^{44}$ Letter of Edwin W. Weissman, Area provost Marshall, 17 June 1946, Police Archives (1945-1949), file 011-4-175: Dec. 1946-Nov. 1948; undated letter from the Italian ambassador, Police Archives (1945-1949), file 011-4-174

${ }^{45}$ Heath, Frances J. (1925) "Review of Eight Years' Work in China in a Gynecologic Out-patient Clinic," China Medical Journal 39, pp. 701-703.

${ }^{46}$ According to the author, 53.4 percent had received no treatment while 36.9 percent had taken Chinese oral medicine. Only 5,9 percent had been treated with salvarsan and 1.6 percent with mercury. Heimburger, L.F. (1927) "The Incidence of Syphilis at the Shantung Christian University Dispensary," China Medical Journal 41, p. 548

${ }^{47}$ Statistics are self-explanatory. From 1927 to 1933, there were 4,681 traditional native physicians and 596 western-trained doctors in Shanghai. The proportion among hospitals was just the opposite. Among the 31 registered establishments, 28 practiced Western medicine and only three offered traditional medicine. Huang Kewu (1988) "Cong Shen Bao yiyao guanggao kan min chu Shanghai de yiliao wenhua yu shehui shenghuo, 1912-1926" (The Medical Culture and Social Life in Shanghai: A Study Based on the Medicine Advertisements in Shen Pao, 1912-1926), Jindaishi yanjiusuo jikan (Bulletin of the Institute of Modern History, Academia Sinica) XVII, part II, p. 149.

${ }^{48}$ The use of mercury in the treatment of syphilis since the Ming dynasty (1368-1644), or even since the eighth century, is borne out by a treatise on the history of medicine in China. However, it is generally considered that syphilis was not introduced into China before the fourteenth century. Wong K.C., Wu Lien-teh (1932) History of Chinese Medicine, Tientsin, Tientsin Press Ltd., pp. 218-219.

${ }^{49}$ Heimburger, L.F. (1927) "The Incidence of Syphilis at the Shantung Christian University Dispensary," op. cit., p. 548.

${ }^{50}$ The rather strange names of these medicines have their origin in the number of experiments made by its inventor, Dr. Ehrlich, from Frankfurt. Salvarsan was born on the 606th attempt, although it was improved afterward through renewed experiments. The 914th one produced Neosalvarsan. Other treatments based on bismuth were also introduced after 1921. Quetel, Claude, History of syphilis, op. cit., pp. 142-143.

${ }^{51} \mathrm{Wu}$, Lien-teh (1927) "The Problem of Venereal Diseases in China," China Medical Journal 41, p. 34.

${ }^{52}$ Ji Longsheng [1942] Da Shanghai (« Greater Shanghai »), Taibei, Nanfang zazhi chubanshe p. 111.

${ }^{53} \mathrm{SB}$, advertisement, 15 Aug. 1928

${ }^{54}$ Ji Longsheng, Da Shanghai, op. cit., p. 111.

${ }^{55}$ Huang Kewu, "Cong Shen Bao yiyao guanggao kan min chu Shanghai de yiliao wenhua yu shehui shenghuo, 1912-1926," op. cit., pp. 141-194

${ }^{56}$ Huang Kewu, "Cong Shen Bao yiyao guanggao kan min chu Shanghai de yiliao wenhua yu shehui shenghuo, 1912-1926," op. cit., p. 162-163, p. 168 and p. 180.

${ }^{57}$ Cf. $S B, 12$ Sept. 1899

${ }^{58}$ Archives of the Secretariat. International settlement (Secretariat, Shanghai Municipal Council) (19201924), Shanghai Municipal Archives: 3-00445: File 1486, part 3, Secretariat (SMC), "Prostitution: Brothels: Withdrawal of licenses, 1920-1924".

${ }^{59}$ The other titles of newspapers that were collected (undated, [April 1930]) are: Xiaoxiao da mimi (Big and Small Secrets), Liyuan gongbao (The Player), Qiongbao (Jade), Xiaoribao (The Little Daily), 
Shanghaitan (The Shanghai Bund), Que'ersideng (The Cherleston), Da shanghai (Greater Shanghai), Qingsi (The Thread of Feeling), Lingbao (The Bell), Shangsheng (The Voice of Commerce), Fu'ermosi (?). ${ }^{60}$ Huang Kewu, "Cong Shen Bao yiyao guanggao kan min chu Shanghai de yiliao wenhua yu shehui shenghuo, 1912-1926," op. cit., p. 162, p. 173 and pp. 182-183.

${ }^{61}$ Ji Longsheng, Da Shanghai, op. cit., p. 111.

${ }^{62}$ Wu, Lien-teh, "The Problem of Venereal Diseases in China," op. cit., p. 34.

${ }^{63}$ Cf. Shanghai zhinan (1919) (Guide to Shanghai: A Chinese Directory of the Port), Shanghai, Shangwu yinshuguan, (1 ${ }^{\text {st }}$ ed., 1909), V, p. 19.

${ }^{64} \mathrm{Yu}$ Wei (1948) "Shanghai changji wu bai ge an diaocha" (A survey of five hundred Shanghai prostitutes), Shizheng pinglun (The Municipal affairs weekly) 10:9/10, p. 13.

${ }^{65}$ Shanghai Municipal Council, Report for the Year 1923, op. cit., p. 125.

${ }^{66}$ Sources for table 1: Shanghai Municipal Council, Report for the Year 1923, p. 123; 1924, p. 148; 1925, p. $134 ; 1926$, p. $196 ; 1927$, p. $182 ; 1929$, p. $150 ; 1930$, p. $166 ; 1931$, p. $148 ; 1932$, p. 175 , 1933 , p. 170 ; 1934 , p. $137 ; 1935$, p. $116 ; 1936$, p. $144 ; 1937$, p. $153 ; 1938$, p. $174 ; 1939$, p. $152 ; 1940$, p. 178.

${ }^{67}$ The table includes two supplementary columns: one for the patients who had two different diseases and one for those who suffered from various unidentified infections.

68 "Report on the Control and Treatment of Venereal Disease in Shanghai" (1924) China Medical Journal, Supplement, 38, pp. 19-21.

${ }^{69}$ Yu Wei, "Jin chang yu xingbing fangzhi," op. cit., p. 17

${ }^{70}$ In Shanghai, the whole population was subject to quick blood samples (ear) to detect syphilis. Around 3,600 persons were mobilized to carry out this campaign over a short period of time. Horn, Joshua S. (1971) Away With All Pests. An English Surgeon in People's China: 1954-1969, London/New York, Monthly Review Press, p. 92; Banister, Judith (1987) China's Changing Population, Stanford, Stanford University Press, pp. 53-54.

71 "Xingbing he jiyuan" (STDs and brothel houses), Wenhuibao, 25 Nov. 1951, p. 72

${ }^{72}$ Lai, Dr. (1930) "Syphilis and Prostitution in Kiangsu," China Medical Journal 44, pp. 559-560.

${ }^{73}$ To detect syphilis, the dispensary used the Wasserman test. For gonorrhea, the physicians resorted to cervical smear. Unfortunately, they kept no statistics of this infection. Yu Wei, "Shanghai changji wu bai ge an diaocha," op. cit., p. 13.

${ }_{74}^{74}$ Yu Wei, "Shanghai changji wu bai ge an diaocha," op. cit., p. 13.

${ }^{75}$ In 1946, among the 931 diseased prostitutes treated in the dispensary, 233 contracted another venereal infection during the time of their treatment. This is an indication of the fact that the prostitutes, although they were diseased, did not stop practicing their trade in violation of the regulation. Yu Wei, "Jin chang yu xingbing fangzhi," op. cit., p. 18.

${ }^{76}$ Letter of the Bureau of Health, 30 Oct. 1946, Police Archives (1945-1949), file 011-4-269.

${ }^{77}$ He Wannan, Yang Jiezeng (1988) Shanghai changji gaizao shihua ("A Short History of the ReEducation of Prostitutes in Shanghai "), Shanghai, Sanlian shudian, p. 73. It must also be borne in mind that the new communist authorities were eager to show the extent of the damage and may have exaggerated the results.

${ }^{78}$ Taxi dancers were female professional dancers who could be hired for dancing in the dancing halls that flourished in Chinese cities after W.W.I. See See Henriot, Christian (2001) Prostitution and Sexuality in Shanghai. A Social History (1849-1949), New York, Cambridge University Press, chap. 4.

${ }^{79}$ Lai, Daniel (1948) "Incidence of Syphilis among Prostitutes and Cabaret Hostesses in Tsingtao," Chinese Medical Journal 66, pp. 389-90.

${ }^{80}$ This was an experiment aimed at testing a new medicine against gonorrhea on a group of prostitutes through the comparison with a similar sample that did not take the medicine. The experiment was a failure in terms of medical protection.

${ }^{81}$ This is an average number. The higher the number of visits, the higher the probability that a woman was found to have an infection. Those who came more than five times during the time of the survey were all tested positive. An age group analysis revealed that those between 20 and 29 years had the highest rates of infection. Chu L.W., Huang C.H. (1948) "Gonorrhea Among Prostitutes" [Peking], Chinese Medical Journal 66, pp. 312-18.

${ }^{82}$ Xing bing zai Zhongguo, (STDs in China) (1990) Beijing, Beijing shiyue wenyi chubanshe, p. 4. 
${ }^{83}$ At this time, a visit at the dispensary cost only 20,000 yuan. In July 1948, it was raised to 60,000 yuan because of inflation. Letters of the Bureau of Health, 22 Nov. 1947; 2 July 1948, Police Archives (19451949), file 011-4-269.

${ }^{84}$ Police report, undated, Police Archives (1945-1949), file 011-4-263: Oct. 1947.

${ }^{85}$ Statement of a prostitute, 18 Oct. 1947, Police Archives (1945-1949), file 011-4-263: Oct. 1947.

${ }^{86}$ Statement of a prostitute, 15 June 1948, Police Archives (1945-1949), file 011-4-269.

${ }^{87}$ Letter of the Bureau of Health, 2 Dec. 1946, Police Archives (1945-1949), file 1-10-246: May 1946-Jan. 1949

${ }^{88}$ Yu Wei, "Jin chang yu xingbing fangzhi," op. cit., p. 18.

${ }^{89}$ This, in turn, also varied over time. After the mid-1930s, the state of virtual slavery which characterized the situation of a very large segment of the prostitutes virtually disappeared. Before that, however, many prostitutes completely lost their freedom during the time they served in a brothel. On the condition of prostitutes, see Henriot, Christian, Prostitution and Sexuality in Shanghai, op. cit. chapter 9.

${ }^{90} S B, 14$ Oct. 1899.

${ }^{91} S B$, 29 Sept. 1909.

${ }^{92} S B, 2$ April 1921. It is true that the madams were afraid that the prostitutes would take the opportunity of going out or staying at a hospital to run away as many actually did. $S B, 17$ May 1920; 2 April 1921.

93 At the end of the century, the walled city in Shanghai had a large number of opium dens where customers were attended by young women who also provided sexual services. Originally, these places were just opium dens which, in order to compete with each other and attract customers, recruited or simply purchased young girls to replace male waiters. Very soon, these girls were pushed into prostitution, whence the name of their establishments huayanjian or yanhuajian (literally "chambers of smoke and flowers"). See Henriot, Christian (2001) Prostitution and Sexuality in Shanghai. A Social History (1849-1949), New York, Cambridge University Press, chap. 3.

${ }_{94} S B, 20$ April 1924.

${ }^{95}$ Henriot, Christian, "Modern Medicine, V.D., and Prostitution in Pre-Revolutionary China,” op. cit. p. 105.

${ }^{96}$ Horn, Joshua S., Away With All Pests, op. cit.

${ }^{97}$ Henriot, Christian (1993) Shanghai, 1927-1937. Elites, locality, and municipal power in Nationalist China, Berkeley, University of California Press, chap. 8.

98 Henriot, Christian (1995) " "La Fermeture": The Abolition of Prostitution in Shanghai, 1949-1958, " The China Quarterly, December, pp. 148-167; Beijing fengbi jiyuan jishi (1988) ("The True Story of the Closure of the Houses of Prostitution in Peking "), Beijing, Zhongguo heping chubanshe; He Wannan, Yang Jiezeng, Shanghai changji gaizao shihua, op. cit.

${ }^{99}$ For a genuine attempt at understanding prostitution in China, see the newly released study by Pan Suiming (1999) Zhongguo hongdengqu jishi (A True Record of China's Red Light Districts), Beijing, Qunyan chubanshe. 


\section{References}

"Commercialized Vice in China" (1922) National Medical Journal 8:3, pp. 396-397

"Report on the Control and Treatment of Venereal Disease in Shanghai" (1924) China Medical Journal, Supplement, 38, pp. 19-21.

Archives diplomatiques, Nantes. Minutes of the Commission d'administration municipale, 29 Dec. 1926, Ordonnances consulaires (Jul. 1926-Dec. 1928) - , Box No 39.

Archives of the police (jingchaju) (1945-1949). File 011-4-269; file 011-4-261; file 1-10-246; file 6-19-666; file 011-4-171; file 011-4-161; file 011-4-174; file 011-4-263

Archives of the Secretariat. International settlement (Secretariat, Shanghai Municipal Council) (1920-1924), Shanghai Municipal Archives: 3-00445: File 1486

Banister, Judith (1987) China's Changing Population, Stanford, Stanford University Press.

Beijing fengbi jiyuan jishi (1988) ("The True Story of the Closure of the Houses of Prostitution in Peking "), Beijing, Zhongguo heping chubanshe.

Benedict, Carol (1996) Bubonic Plague in Nineteenth-Century China, Stanford, Stanford University Press.

Chu L.W., Huang C.H. (1948) "Gonorrhea Among Prostitutes" [Peking], Chinese Medical Journal 66, pp. 312-18.

Fearn, Anne W. (1939) My Days of Strength: An American Woman Doctor's Forty Years in China, New York, Harper \& Brothers Publishers.

Frazier, Chester N. (1937) "The Prevention and Control of Syphilis," Chinese Medical Journal 51: January, pp. 1043-46

He Wannan, Yang Jiezeng (1988) Shanghai changji gaizao shihua ("A Short History of the Re-Education of Prostitutes in Shanghai "), Shanghai, Sanlian shudian.

Heath, Frances J. (1925) "Review of Eight Years' Work in China in a Gynecologic Outpatient Clinic," China Medical Journal 39, pp. 701-705.

Heimburger, L.F. (1927) "The Incidence of Syphilis at the Shantung Christian University Dispensary," China Medical Journal 41, pp. 541-50

Henriot, Christian (1992) "Medicine, V.D., and Prostitution in Pre-Revolutionary China," Social History of Medicine V:1, pp. 95-120

Henriot, Christian (1993) Shanghai, 1927-1937. Elites, locality, and municipal power in Nationalist China, Berkeley, University of California Press.

Henriot, Christian (1995) " "La Fermeture": The Abolition of Prostitution in Shanghai, 19491958, " The China Quarterly, December, pp. 148-167

Henriot, Christian (2001) Prostitution and Sexuality in Shanghai. A Social History (18491949), New York, Cambridge University Press.

Horn, Joshua S. (1971) Away With All Pests. An English Surgeon in People's China: 19541969, London/New York, Monthly Review Press.

Huang Kewu (1988) "Cong Shen Bao yiyao guanggao kan min chu Shanghai de yiliao wenhua yu shehui shenghuo, 1912-1926" (The Medical Culture and Social Life in Shanghai: A Study Based on the Medicine Advertisements in Shen Pao, 1912-1926), Jindaishi yanjiusuo jikan (Bulletin of the Institute of Modern History, Academia Sinica) XVII, part II, pp. 141-94.

Ji Longsheng [1942] Da Shanghai (« Greater Shanghai »), Taibei, Nanfang zazhi chubanshe.

Lai, Daniel (1948) "Incidence of Syphilis among Prostitutes and Cabaret Hostesses in Tsingtao," Chinese Medical Journal 66, pp. 389-90.

Lai, Dr. (1930) "Syphilis and Prostitution in Kiangsu," China Medical Journal 44, pp. 558563.

Le Journal de Shanghai, 1931 
MacPherson, Kerrie L. (1987) A Wilderness of Marshes. The Origins of Public Health in Shanghai, 1843-1893, Oxford, Oxford University Press.

Pan Suiming (1999) Zhongguo hongdengqu jishi (A True Record of China's Red Light Districts), Beijing, Qunyan chubanshe.

Peter, W.W. (1921) “Fighting Venereal Disease Openly," China Medical Journal 35: January, pp. 61-66

Quetel, Claude (1990) History of syphilis, Baltimore, The Johns Hopkins University Press.

Rogaski, Ruth (1996) "From protecting life to protecting the nation: The emergence of public health in Tianjin, 1859-1953," doctoral dissertation, Yale University.

Shanghai Municipal Council (1920-1940) Report for the Year ..., Shanghai, Kelly \& Walsh.

Shanghai zhinan (1919) (Guide to Shanghai: A Chinese Directory of the Port), Shanghai, Shangwu yinshuguan, (1st ed., 1909).

Shen Bao, Shanghai, daily, 1920-1925

Wong K.C., Wu Lien-teh (1932) History of Chinese Medicine, Tientsin, Tientsin Press Ltd., pp. 218-219.

Wu, Lien-teh (1927) "The Problem of Venereal Diseases in China," China Medical Journal, vol. 41: January, pp. 28-36.

Wu, Lien-teh (1927) "The Problem of Venereal Diseases in China," China Medical Journal 41, p. 34.

Xing bing zai Zhongguo, (STDs in China) (1990) Beijing, Beijing shiyue wenyi chubanshe.

Yewu baogao (Annual report) (1941) Shanghai, Shanghai tebie shi weishengju bian.

Yewu baogao (Annual report) (1942) Shanghai, Shanghai tebie shi weishengju bian.

Yip Ka-che (1995) Health and National Reconstruction in Nationalist China. The Development of Modern Health Services, 1928-1937, Ann Arbor, Association for Asian Studies.

Yu Wei (1948) "Jin chang yu xingbing fangzhi" (The prohibition of prostitution and the prevention of venereal diseases), Shizheng pinglun (The Municipal affairs weekly) 9:9/10, pp. 17-18.

Yu Wei (1948) "Shanghai changji wu bai ge an diaocha" (A survey of five hundred Shanghai prostitutes), Shizheng pinglun (The Municipal affairs weekly) 10:9/10, pp. 10-14. 